This is an original manuscript / preprint of an article published by Taylor \& Francis in CREATIVE INDUSTRIES JOURNAL on 12 Aug 2019, available online:

http://www.tandfonline.com/doi/full/10.1080/17510694.2019.1652024

The Limits of Low-Cost Cinema in Spain: an Analysis of the \#Littlesecretfilm Movement

\title{
Antonio Loriguillo-López
}

Universitat Jaume I of Castellón, Spain

loriguil@uji.es

Postal address: Office HC1048DD, Departamento de Ciencias de la Comunicación, Facultad de Ciencias Humanas y Sociales, Universitat Jaume I de Castellón. Campus del Riu Sec, Av. Sos Baynat, s/n, E-12071 Castellón de la Plana

\section{Agustín Rubio Alcover}

Universitat Jaume I of Castellón, Spain 


\section{The Limits of Low-Cost Cinema in Spain: an Analysis of the \#Littlesecretfilm Movement}

The self-styled \#Littlesecretfilm phenomenon is a low-cost film production and distribution movement that was launched in Spain in 2013. Based on a reconstruction and examination of its development from its foundation (with the publication of a manifesto in the form of ten commandments) through to its products (a full survey of which are presented here), this article offers a meaningful and not entirely uncritical snapshot of a conscious proposal of a low-cost production model in contemporary Spain. In our conclusion, we tie this film movement in with international debates about the viability of a low-cost approach in the context of a national film industry that has been left badly battered by the financial crisis that began in 2008 .

Keywords: low-cost film, contemporary Spanish film, independent cinema, Spanish film industry 


\section{Introduction}

The objective of this research is to present the first comprehensive overview of the latest successful organised movement in the history of the Spanish film industry: \#Littlesecretfilm. Our purpose is to reconstruct the evolution of \#Littlesecretfilm since its establishment in 2013, with a special focus on analysing its ambitions in the industrial-economic and narrativeaesthetic contexts in which it has arisen, both domestically and internationally. To this end, we propose to offer an initial (quantitative) assessment of its results, followed by an outline of the main features and constants of films produced under this label. The ultimate aim is to place this initiative in the contemporary context of film production and distribution and what has come to be referred to as 'shadow economies of cinema' (Lobato, 2012), and to determine the real degree of discursive originality of the project in light of the long and winding trajectory of the movements established in opposition to the Hollywood mainstream over the course of the twentieth century (Romaguera i Ramió and Alsina Thevenet, 1998) under the increasingly unenlightening label of 'independent cinema' (King, Molloy and Tzioumakis, 2013), a dead end explored exhaustively by Dogme 95 in the years leading up to the turn of the millennium (Ostrowska, 2005; Rubio Alcover, 2010).

The authors of this article engaged in extensive dialogue with the main founders of the movement, the filmmaker Pablo Maqueda ${ }^{\mathrm{i}}$ and the producer Haizea G. Viana, who drafted a manifesto consisting of ten rules with the intention of launching what they themselves called a 'film production model' that would stimulate creativity and a sense of risk among creators on the basis of a set of limitations (Maqueda and Viana, 2013):

(1) The film will be produced secretly, without promotion of any kind in media or social networks until the première. 
(2) Each director will have a maximum of 24 uninterrupted hours for filming the movie. No time limits for pre and posproduction [sic].

(3) The film will be shot with digital cameras. The director may include stock footage, regardless of its format.

(4) If the film is fictional, the dialogues will be ad-libbed. The director and the artistic crew will be featured as scriptwriters in the credits.

(5) The artistic and technical crew can't be over ten members in total. No member of the team will sign any legal document regarding the making of the film or receive a salary for his/her collaboration.

(6) The film will be funded exclusively by the director. Any king of external support or funding brought by third parties will be forbidden.

(7) The film will be released freely on the Internet with a non-commercial Creative Commons license.

(8) The director will distribute his/her \#littlesecretfilm in any web server of his/her election, including, with the title of the film, the hashtag \#littlesecretfilm.

(9) \#littlesecretfilm is not a new cinematic movement, school or brand. It's a non-commercial film production model, based on the establishment of boundaries, risk, improvisation and the influence of chance, confronted to the long and painful processes of writing, preproduction, funding, shooting and edition involved in the creation of [a] cinematographic feature film. A defense of [the] Internet as a medium to distribute films. An act of love for the cinema, on behalf of a small team of professionals yearning [to tell] stories, experiment, [and] enjoy the act of creation.

(10) \#littlesecretfilm aims to be a different way to produce, direct, distribute, release, watch, feel and love cinema.

As confirmed by the project's promoters (and the drafters of the manifesto, one of whom is the director and co-writer while the other is the producer of two of the films associated with the 
movement, and both of whom are executive producers of much of the first wave and of the films produced with the support of Calle $13^{\mathrm{ii}}$ ), the history of \#Littlesecretfilm can be effectively divided into three stages:

(1) The first stage, orchestrated entirely on the movement's website (http://littlesecretfilm.com/). In this stage, Maqueda and Viana's contacts in the audiovisual sector who received an invitation to join the initiative, with the guarantee that they would maintain absolute creative freedom, took up the offer and began making the movement's first titles. Although it had been gestating since late 2012, the movement's first flourishing took place between 28 January 2013, the date on which the manifesto was published and the upcoming release of the first batch of films was announced, and 1 February, when the release of the 16 original films was jointly and simultaneously communicated to the public.

(2) The second stage, marked by the entry of Calle 13 into the movement. This represented a significant leap forward in terms of the screening possibilities for the films produced under its sponsorship, the promotional support and, therefore, the potential impact both of the new films (thirteen initially) and, by extension, of the initiative as a whole. The release of these productions, for which special screenings were held at Madrid's La Cineteca film theatre, took place on 22 July 2013.

(3) The third stage, involving the internationalisation of the movement, still in progress. The results of this stage — notably including \#Sequence, a collective film shot entirely on the same day (21 December 2013) in accordance with the postulates of the movement, and with the sponsorship of NotodoFilmFest and the backing of the filmmaker Montxo Armendáriz — have been less focused. Partly overlapping with the second stage, due to the fact that the web release of some films that had already been 
produced but did not yet have the support of Calle 13 was delayed so as not to distract attention from those that already had been, this later stage has taken some contradictory and somewhat bittersweet turns. On the one hand, it has seen the expansion and global recognition of the initiative, with the as yet unrealised but very real possibility that the example may be followed beyond Spanish borders not only by creators on the industry's fringes, but also with the active participation of some major players. On the other, it has been marked by a languishing and even a certain distortion of the original initiative, in a process identical to that of practically every other countercultural movement that has enjoyed any degree of influence over the course of film history.

Thus, as a general assessment (arguably provisional, given that the movement, always open to spontaneous additions, currently finds itself at an impasse or hiatus that may prove permanent), \#Littlesecretfilm has been a success story, as confirmed by the appearance at national film festivals of several feature films promoted practically without resources or with very modest budgets by filmmakers with limited experience who were finding it hard not just to break into the industry but even to attract attention on the fringes of the system, ${ }^{\text {iii }}$ and the interest of some players in Spain's VoD segment and distributors for the home video market.

The parallels with the fate of other projects aiming to challenge, revitalise or revolutionise the film industry that have been met with success in the past invites us to consider the precursors to \#Littlesecretfilm. When asked about the influence of Dogme 95 in the development of the manifesto, Maqueda responded that his idea was closer to the coordinates of innovative creativity of mumblecore, a film movement that emerged in the United States in the first years of the new millennium that sought to portray the lives of characters tackling the responsibilities 
and disappointments of adult life in a naturalist style and with an emphasis on dialogue (Murphy, 2017).

\section{Current state of Spanish film production: precariousness and the digital crossroads}

Our object of study poses an interesting novelty thanks to its status as a rare bird within what could be called 'movie microeconomics' (McKenzie, 2012), given that, although not a profitdriven commercial operation, the movement vertically integrates cinematic processes, conditioning the production decisively (ten commandments/manifesto) and supporting distribution/screening through the platform of its website. To explore the motivations behind a movement that began as an industry outsider, with a manifesto focusing on the creation of artistic 'underproductions' (Costa, 2013) in record time-in consonance with the 'film sport' concept (Mercier, 2014) promoted by various short film competitions requiring entries to be completed in 24-48 hours and with a series of technical restrictions not unlike those outlined in the manifesto-it is essential to consider, paradoxically but necessarily, the context of the industry and, more specifically, the figures for production, distribution and creative levels of Spanish cinema on the international scene.

The Spanish case does not exhibit particular features that set it apart from film production elsewhere in the world, which can still be classified as a productive sector at a perpetual impasse (Gómez Tarín and Rubio Alcover, 2015: 17). Despite the proposal of tools that can provide data of use for predicting the viability of a film (Ribera and Sieber, 2009; Wirtz, Meremann, and Daiser, 2016), chronic uncertainty continues to be the biggest barrier to investment in the audiovisual sector. Like European cinema in general, the Spanish film sector-with an estimated 72,000 active professionals (Spain Film Commission, 2017)—suffers from 
weaknesses such as the difficulties associated with applying economies of scale due to a high degree of atomisation (Izquierdo Castillo, 2012: 89) and an increasing concentration of media ownership that is especially affecting national film distribution (Artero and Sánchez-Tabernero, 2015: 328). Film production data for 2013 and 2014 (the years in which most of the films in our sample were produced) reflect an upturn in the number of productions released compared to the previous decade (Figure 1), with more than 150 feature films produced in each year (Ministerio de Educación, Cultura y Deporte, 2014: 6).

Figure 1. Evolution of the number of Spanish feature films released between 2004 and 2014 (bottom row). Source: Boletín informativo 2014 (Ministerio de Educación, Cultura y Deporte, 2014).

The entry of Calle 13 in the production of \#Littlesecretfilms brought external private capital into the enterprise through the purchase of broadcasting rights, one of the key processes for securing financing for films in Spain, ${ }^{\text {iv }}$ along with sources of public capital in the form of soft loans or subsidies from the Spanish Institute of Cinematography and Audiovisual Arts (ICAA) for amortisation and production costs (Poveda Criado 2015: 878), funding which is always under scrutiny due to a allegations of nepotism and a lack of transparency (Wheeler, 2014: 13$15)$.

The exploration of online distribution of audiovisual content is another of the key aims of the \#Littlesecretfilm initiative. Distribution in Spain has always been entangled in the controversy, hotly debated in the media, related to the country having the most consistently high levels of piracy in the first world (Donoghue, 2014). On this point, Maqueda stresses that the inclusion of the hashtag in the name of the project was intended to underline the consideration of the Internet not merely as a hotbed of piracy, but as a great opportunity for twenty-first century 
cinema. This represented a very clear stand on the debate raging in those very moments in the industry and in society in general, and in which the President of the Spanish Film Academy himself, the acclaimed filmmaker Álex de la Iglesia, had become directly involved, to his obvious detriment — even to the point of leading to his resignation from the presidency. At the same time, the irregular arrival in Spain of new players on the international media scene, like Netflix (Izquierdo-Castillo, 2015: 825), complicates any prediction regarding their potential integration and possible impact on the Spanish audiovisual industry. And the situation is complicated further still if we consider that, although the popularity of the Internet as the main medium for entertainment has yet to be confirmed in the successive surveys of Spain's Centre for Sociological Research (Centro de Investigaciones Sociológicas, CIS), the fact that the revenues of the online film rental business in Spain have seen an increase in the period 20062011 of more than $600 \%$ (Pardo and Etayo, 2014: 136) is a sign of the growth of online film distribution in the country, an insufficiently researched field in the context of the importance of the transnational in (and in tension with) the configuration of the national (Binimelis, Cerdán and Fernández Labayen, 2015: 2).

The careers of contemporary Spanish filmmakers who do not belong to the 'Los Novísimos' collective (Palacio, Ibañez and Bret, 2015: 29), a generation whose feature films began appearing in the first decade of the new millennium and that includes directors like Javier Rebollo, Jaime Rosales, Mercedes Álvarez, Virgina García del Pino, Mar Coll, Jonás Trueba, Nacho Vigalondo and Pablo Berger, among many others, have largely followed trajectories of decline, outsiderism or compromise, three paths intimately associated with the devaluation (in all its possible senses) of cinema in Spain and with the unassailable view of the feature film as the ultimate aim of every Spanish filmmaker (Rubio Alcover, 2014: 24). The resignation to a precarious living on the part of those aspiring to break into the audiovisual industry in an era 
when euphemisms like 'worker flexibility' predominate in new job position descriptions, a trait identified by Percival and Hesmondhalgh in young workers in the British film and television sector, appears to be shared by their Spanish counterparts who, as these authors suggest, 'increasingly tend to see organizations, and jobs, as opportunities for self-development, rather than as sources of commitment' (2014: 201), and as a result often neglect their commitment to the social contract of their chosen profession in the interests of enhancing their own resumes or simply satisfying their interests and testing their talents.

\section{Materials and methods}

Our analytical sample is made up of a total of 29 of the films associated with the movement. The defining parameter of the sample has been temporal, considering the most representative cases to be films produced during the peak period of the movement, the years 2013 and 2014 (stages 1 and 2). The complete list of the sample can be consulted in the table below (Table 1).

Table 1. List of films comprising the sample: \#Littlesecretfilms released in 2013-2014. Source of online viewing data: official profiles of directors, producers and films on YouTube and Vimeo [last update January 2018].

The heterogeneous group of directors (including only two women compared to thirty-two men) represents the vital forces of Spain's low-cost film movement. First of all, there is a notable number of newcomers who, from the fringes of the Spanish film industry, have made the leap to the feature film. In this list we find digital media film critics (such as Jordi Costa, Héctor G. Barnés, and the Ceballos-Tones duo), the director of the Sitges Film Festival (Ángel Sala), Youtubers like the comic duo Venga Monjas (occasional contributors to the Catalan public 
television comedy series Alguna Pregunta Més? together with Carlo Padial, who also has a film in the sample), and one of the major figures in the Spanish web series phenomenon, director and star of Malviviendo (2008-2014) David Sainz. On the other hand, among the directors with backgrounds in advertising, television, or short films are the founder of the initiative himself, Pablo Maqueda, as well as Miguel Larraya (Afterparty, 2013), Marçal Forès (Animals, 2012) and Bruno Teixidor, co-director and producer of The Cosmonaut, the first major attempt at the crowdfunding approach in Spain. In this respect, it is important to clarify that when asked about the degree of compliance with the manifesto's 'commandments' (especially with regard to the points related to the duration of shooting and the number of team members involved), Maqueda acknowledged that several projects that began their lives as \#Littlesecretfilms dropped out of the initiative because they ended up becoming more ambitious and complex than the restrictions of the movement would allow, such as in the case of Anabel (Antonio Trashorras, 2015), while other directors left the movement when they came to grasp the practical implications of the requirement that their films be available online free of charge with a Creative Commons licence and the consequent impossibility of exploiting them commercially.

The methodology adopted for this study has involved a textual analysis of the narrative and expressive resources of the films, with special attention to the five features which, in our view, are hinted at in Maqueda and Viana's manifesto and reflected in the films that make up the sample, namely:

(1) Metafictional components: metacinema is one of the most popular themes in postmodern films (Thanouli, 2009: 140-141) and especially in shorts and low-budget productions, which abound in allusions to cinematic production processes and references to the status of the film industry of their time. In this respect, the central role played by 'post-cinematic celebrities' (Shaviro, 2010: 7), the aesthetic of the pseudo- 
documentary, and the Youtuber mise-en-scene are some of the most widespread features.

(2) Compressed and circular narrative structure: the limitations of the ten rules tend to enforce a kind of narration with minimal ellipses, where the action in the diegesis takes place within a limited stretch of time (and space, locations), favouring the inclusion of circular story arcs.

(3) Lengthening of scenes and virtuosity of cast. An abundance of verbose characters and a storyboard filled with the codes of docufiction gives rise to the consolidation of a consistent and self-contained performative code, tending towards overacting. Maqueda himself notes the prominence of both sequence shots and actor improvisation and direction. As an illustrative anecdote, the director recalls the work process followed during the seventeen consecutive hours of shooting as a constant process of trial, improvisation and, finally, collective creation together with the star of Manic Pixie Dream Girl, Rocío León, exploring set-ups for parallel plots that would never form part of the diegesis. Another positive feature, according to Maqueda, involves the acceleration of production times, which allowed him to shoot his other film, \#RealMovie, in June and to see it released the following month.

(4) Integration of pastiche into the discourse in an effort to revitalise elements of the mainstream, a feature already visible in the Dogme 95 and mumblecore movements.

(5) Vagueness and ambiguity between pop and subversion: subject to the same contradictions afflicting all contemporary audiovisual products, the filmmakers of the \#Littlesecretfilm collective swing between a (falsely) naive and a genuine (albeit unresolved and perhaps unresolvable) ambition to articulate an alternative proposal.

\section{Results}


The voluntarily secret production conditions of the \#Littlesecretfilms can be seen clearly in some of the more representative features of the sample. The swiftness of the editing process is reflected in the use of textual graphics, which is largely limited to the opening credits and the closing titles with the members of the artistic and technical crew. These narrative microparticles are more prominent in titles produced by Calle 13 - the iconic quality of the main title shots in \#RealMovie, Estado de regresión, Detective Deketto or Círculo interno - than in the movement's productions distributed online-with notable exceptions, like the tribute to Saul Bass's work on Vertigo (Alfred Hitchcock, 1958) in Iron Cock Unchained. It is precisely in this last group of films that we find a conscious use of graphics with a meta-referential purpose and playful intentions: in the appearance of the opening credits in Undo infinito on a DV tape capture interface, the distortion filters in KILN or the display of filters over a slow-motion image in a musical fragment in Desmadre en la noche de la quietud with a certain evocation of the primitive mode of representation. Beyond this, the use of many of the films of the pseudo-documentary style is reflected in the recreation of interspersed video tape footage (for example, the flashbacks in Círculo interno).

Another distinction between the Calle 13 and the web productions emerges in the approach to the soundtracks. Many of the first \#Littlesecretfilms have scores composed by musicians who are regular contributors to Spanish short films: Aaron Rux, Esteban Navarro, or Alejandro Ventura. The incorporation of popular music (a paradigmatic feature of post-modern cinema, but also of amateur films) is limited due to the difficulties associated with securing the rights, which is probably why many of the songs used are integrated into the diegesis. Particularly notable among these are the concerts in Amor eterno, the live performances by the members of the intergalactic supergroup in KILN, the importance to the plot of the songs in Piccolo grande amore and La lava en los labios, the fully musical character of 16th Folk Room, and the rockabilly performance by the group Los Cavernas in Todo el mundo lo sabe. 
In terms of references, a prominent distinction can be observed between what we understand as film genres — within the Spanish tradition of genre experimentation (Beck and Rodríguez Ortega 2008: 2-6), we have identified flirtations with science-fiction (Nova), the slasher genre (Undo infinito, Círculo interno, Obra 67), the action thriller (\#RealMovie), political cinema (Todo el mundo lo sabe, Estado de regresión), the detective film (Detective Deketto) and, above all, the pseudo-documentary (KILN, Working Progress, Los amigos raros) —on the one hand, and an effort to produce an auteur style on the other.

Also in this respect, the vast majority of the films associated with the movement weave in elements of contemporary family drama (couple relationships, responsibility in the context of job insecurity, the growing pains of adolescence), often through a prism of irony, along with metafiction, which, apart from plots that include film shoots, editing rooms and screenings, is reflected in constant references to the omnipresence of social networks and the economy of handles, visits and likes, essential terminology in the everyday lives not only of pseudocelebrities (like the multifaceted character of Rocío León in Manic Pixie Dream Girl or Kristina lofyiu in Neuroworld) or those aptly defined by Jordi Costa himself as 'crypto-filmmakers' (2013) who are featured in titles like Los desórdenes sentimentales or Cinema Verité, Verité, but also of the creators of the films themselves.

The restrictions imposed by the manifesto leave a particularly strong mark on the last factors to be analysed here, related to the dramatic style emerging from the sample of films. The first of these factors is the compressed temporal construction, understandable if we take into account the limitation to a maximum of twenty-four uninterrupted hours of shooting, rich in ellipses and limited in flashbacks, ${ }^{\mathrm{v}}$ with a division into acts that reflects the low number of scenes and locations (e.g. the five acts, each one approximately fifteen minutes long, making up Todos tus secretos), with a prominent use of sequence shots of around ten minutes in length. Associated with this feature, the dramatic structures are complex, often underpinned by a circularity in 
which the final sequence rhymes with the first (Los amigos raros, Círculo interno, Dos tristes tigres, Los desórdenes sentimentales, Manic Pixie Dream Girl, and \#RealMovie).

On the other hands, the mise-en-scene and editing codes could be classified as conventional and, in addition to the occasional incorporation of generic codes mentioned above, include occasional POV shots from smartphones, webcams and website interfaces reminiscent of platforms like YouTube or video-callers like Skype (with the exception of Todos tus secretos, where this is the main technique used throughout the film). Finally, improvisation is one of the defining features of the performances of the actors in the \#Littlesecretfilms, an inevitable feature given the aforementioned time-frame and self-imposed limitations on the production conditions. The virtuosity displayed by the actors, many of whom are regulars of Spanish independent film and television — the aforementioned Rocío León, Íngrid García Jonsson (star of Hermosa juventud by Jaime Rosales, 2014; among others), Julián Genisson (a member of the Canódromo Abandonado collective), and others-is, in accordance with the requirements set out in the manifesto, duly reflected in the credits.

\section{Discussion}

In a Spanish film industry whose mainstream has not remained immune to the more prominent trends in American commercial cinema-from the current ascendency of the complex thriller and the horror genre to the prominence of big-budget 3D animation films (Marzal-Felici and Soler-Campillo, 2013) — the \#Littlesecretfilms constitute a kind of hybrid between auteur productions and the commercial mainstream. ${ }^{\text {vi }}$ These films are largely low-budget productions with conventional distribution in their targeting of adult audiences. ${ }^{\text {vii }}$ The \#Littlesecretfilms explore many of the social issues depicted both in realist cinema critical of the current job insecurity (van Liew, 2010; Allbritton, 2014) and in Spanish fiction shorts (Cea Navas, 2015: 
290-296), with a special emphasis on the employment situation, social addictions (among which we could include addiction to social networks), and family structures.

Despite its democratising objective, which is supported by the online distribution, the movement has ultimately fallen back on an audiovisual 'centralism' if we consider the production locations of the films in the sample, most of which were produced in Madrid. Although according to Maqueda this is explained by the fact that most of his contacts are located in this city, ${ }^{\text {vii }}$ which is one of the nerve centres of the sector in Spain thanks to its large population of film students and privileged status as home to the Spanish film and television industry (Smith, 2009: 65-66), along with its importance as the setting of many of the most prominent Spanish films on international markets (Camino, 2005). In this respect, despite the intention to facilitate distribution of the films by means of a CC3.0 licence, their free accessibility and the possibility of online viewing, ${ }^{\text {ix }}$ \#Littlesecretfilm productions have not had an impact outside the national festival circuit — the one exception being the extremely popular Los amigos raros - probably because these films, due to the limited infrastructure established for their promotion, but also due to their cultural specificity (e.g. the references to film and television vedettes in Desmadre en la noche de la quietud), have ended up appealing mainly to a local market and, as a result, constitute yet another example of 'embedded films' (Herrero, 2014: 534).

It is, perhaps, the perfect metaphor (or a metaphorization?) for the unconscious desire and contradictory fate of contemporary low-cost cinema: employing devices to textualise the way in which those same devices transform reality... without managing to transcend triviality, except in the diegesis. In any case, it remains to be seen whether the \#Littlesecretfilm movement will ultimately produce, as in the case of the film theatres rescued by the Xarxa Cinema association (Arnau Roselló, 2016), a genuinely regenerative and representative transformation of cultural activity led by the public and by civil society. 


\section{Notes}

${ }^{\mathrm{i}}$ This interview was conducted by video conference on 25 April 2017.

ii Calle 13 is a television channel specialising in thrillers and action films. It is owned by the local branch of Universal Studios Networks, and has been available on most cable and satellite television platforms since 1999.

iii Canal+ Award at the 2015 Málaga Festival for Todos tus secretos; Best Film, Best Actor, and Best Screenplay Awards at the 2015 Málaga Festival for Todo el mundo lo sabe; People's Choice Award at the 2015 FKM Fantasy Film Festival in A Coruña for Neuroworld; Premio Noves Visions: Emergents at the 2014 Sitges Festival for Amor eterno.

iv The uncertainty has been responded to on the fringes of the industry with one of the most popular strategies in contemporary audiovisual production: crowdfunding, whose biggest initiatives, launched both by industry veterans-for example, The Apostle (O Apostolo, F. Cortizo, 2012) - and by newcomers-The Cosmonaut (El cosmonauta, N. Alcalá, 2013) - have already been explored in other studies on Spain (Martínez Gallardo and Alberich Pascual, 2013; Altabás, 2014) and Greece (Papadimitriou, 2017).

v A notable exception is the case of the aesthetically marked flashbacks in Círculo interno, which were produced by the creators of the Spanish web series Croatian Files (JJ Torres and Miguel Ortiz, 2013-2014).

vi Although this hybridisation is pointed out in most Spanish film research (Davies, 2005), in recent years the scales seem to have tipped decidedly towards the genre niche if we take into account that the works of filmmakers like Alejandro Amenábar or Jaume Balagueró (Goss, 2017) have helped turn them into 'directores mediáticos', or media-friendly directors (Triana-Toribio, 2008: 260). Notable recent projects, such as the production of HBOstyle series (García-Mainar, 2016) like Crematorio (J. Sánchez-Cabezudo, Canal +, 2011), appear to confirm this trend. For some Hispanists, this genre specialisation of Spanish cinema is significant in that it represents the decline of a recognisably Spanish film tradition, a role destined to become the exclusive property of romantic comedies for all audiences (Buse and Triana Toribio, 2015) like Ocho apellidos vascos (E. Martínez Lázaro, 2014).

vii This is a classification, moreover, always dependent on the film boards regulating the commercial circuits, but not a crucial factor in the case of autonomous online distribution (as noted by Huang, Markovitch and Strijnev, 2013: 53).

viii Notable exceptions are Obra 67 and Amor eterno, two of the most widely acclaimed films of the movement. The former film was produced in one 'peripheral media hub' (Sanson, 2014) in Spain, Seville. The latter was produced in the other 'media city' (Foord, 2009) of the country, Barcelona.

${ }^{\mathrm{ix}}$ A plainly astute strategy given that the one-hour format of the films would make it unlikely for them to be picked up for screening in commercial theatres.

\section{Acknowledgements}

The authors would like to thank Pablo Maqueda and Haizea G. Viana for the documentation provided and for agreeing to be interviewed. We are also grateful to Miguel Larraya, Jordi Costa, Elena Manrique and Borja Crespo for granting access to their films.

\section{References}


Allbritton, D. 2014. "Prime risks: the politics of pain and suffering in Spanish crisis cinema." Journal of Spanish Cultural Studies 15 (1-2): 101-115.

Altabás Fernández, C. 2014. “Autofinanciación y crowdfunding: Nuevas vías de producción, distribución y exhibición del cine español independiente tras la crisis financiera española.” Historia y Comunicación Social 19 (Esp): 387-399.

Arnau Roselló, R. 2016. "Independent cooperatives between film exhibition and cultural management: citizen cinema at the industry's periphery." OBETS. Revista de Ciencias Sociales 11 (2): 419-439.

Artero, J. P., and Sánchez-Tabernero, A. 2015. "Media and telecommunications concentration in Spain (1984-2012).” European Journal of Communication 30 (3): 219-336.

Beck, J. and Rodríguez Ortega, V. 2008. “Introduction”. In Contemporary Spanish cinema and genre, edited by J. Beck and V. Rodríguez Ortega, 1-23, Manchester: Manchester University Press.

Binimelis, M., Cerdán, J., and Fernández Labayen, M. 2015. "In and out: the transnational circulation of Spanish cinema in digital times." Journal of Spanish Cultural Studies 16 (12): $1-8$.

Buse, P., and Triana-Toribio, N. 2015. "Ocho apellidos vascos and the Comedy of Minor Differences." Romance Quarterly 62 (4): 229-241.

Camino, M. M. 2005. “'Madrid me mata': Killing the Husband in Alex de la Iglesia's La comunidad (2000) and Pedro Almodóvar's ¿Qué he hecho yo para merecer esto!! (1984).” Forum for Modern Languages Studies 41 (3): 332-341.

Cea Navas, A. I. 2015. "Social representation in Spanish shorts fiction.” Opción 31(Especial 4): $279-300$.

Costa, $\quad$ J. $2013 . \quad$ "Los conjurados." eldiario.es. http://www.eldiario.es/Kafka/conjurados_0_98340253.html [accesed in February 2018] 
Davies, A. 2005. "Can the contemporary crime thriller be Spanish?" Studies in European Cinema 2(3): 173-183.

Donoghue, C. B. 2014. "Death of the DVD market and the rise of digital piracy: Industrial shifts in the Spanish film market since the 2000s." Quarterly Review of Film and Video 31(4): 350-363.

Foord, J. 2009. "Strategies for creative industries: an international review." Creative Industries Journal 1 (2): 91-113.

García-Mainar, L. M. 2016. "Crematorio or a local case of a global crime film/television.” Hispanic Research Journal 17 (1): 49-61.

Gómez Tarín, F. J. and Rubio Alcover, A. 2015. "Entre el ocio y el negocio." adComunica. Revista Científica de Estrategias, Tendencias e Innovación en Comunicación 10: 17-19.

Goss, B. M. 2017. "The pain in Spain: An analysis of horror auteur Jaume Balagueró's films.” Studies in European Cinema 14 (1): 66-81.

Herrero, C. 2014. "Hybrid Models: Auteurism and Genre in Contemporary Spanish Crime Thrillers." In (Re)Viewing Creative, Critical and Commercial Practices in Contemporary Spanish Cinema, edited by D. Wheeler and F. Canet, 352-364, Bristol: Intellect.

Huang, D., Markovitch, D. G., and Strijnev, A. 2013. "Exploring the small movie profitability puzzle." Marketing Letters 26 (1): 43-55.

Izquierdo Castillo, J. 2012. "El fomento del cine europeo y su comercialización. Estudio comparado de los cines español y francés.” Iconol4 10 (1): 79-93.

Izquierdo-Castillo, J. 2015. "The new media business concept led by Netflix: a study of the model and its projection into the Spanish market." El Profesional de la Información 24 (6): 819-826. 
King, G., Molloy, C., and Tzioumakis, Y. 2013. "Introduction.” In American independent cinema: indie, indiewood and beyond, edited by G. King, C. Molloy and Y. Tzioumakis, 1-8, London: Routledge.

Lobato, R. 2012. Shadow economies of cinema: mapping informal film distribution. Basingstoke: British Film Institute.

Maqueda, P., and Viana, H. G. 2013. "\#Littlesecretfilm Manifesto.” Available online at: http://littlesecretfilm.com/LittlesecretfilmManifestoEnglish.pdf [accesed in February 2018]

Martínez Gallardo, F. D., and Alberich Pascual, J. 2013. "Plataformas y proyectos de crowdsourcing y crowdfunding cinematográfico en España (2007-2011).” Historia y Comunicación Social 18 (Esp): 85-95.

Marzal-Felici, J., and Soler-Campillo, M. 2014. "Contemporary Spanish animated films: Between the temptation of the mainstream and the consolidation of a national cinema." Hispanic Research Journal 15 (1): 88-99.

McKenzie, J. 2012. "The economics of movies: a literature survey." Journal of Economic Surveys 26(1): 42-70.

Mercier, O. R. 2014. "Film sport: Constraint and unrestraint in the 48-Hour Film Competition." New Cinemas: Journal of Contemporary Film 12 (3): 191-204.

Ministerio de Educación, Cultura y Deporte. 2014. Boletín informativo 2014. Madrid: Gobierno de España.

Murphy, J. J. 2017. “Looking through a Rearview Mirror: Mumblecore as Past Tense.” In A Companion to American Indie Film, edited by G. King, 279-299, Hoboken: Wiley Blackwell.

Ostrowska, D. 2005. "Zentropa and Von Trier: A marriage made in heaven." Studies in European Cinema, 2 (3), 185-198. 
Pardo, A., and Etayo, C. 2014. "Movies and screens: The Spanish audience's choice." Communication and Society 27 (4): 131-145

Palacio, M., Ibañez, J. C., and Bret, L. 2015. “A new model for Spanish cinema. Authorship and globalization: the films of Javier Rebollo." Journal of Spanish Cultural Studies 16(1): $29-43$.

Papadimitriou, L. 2017. "Transitions in the Periphery: Funding Film Production in Greece Since the Financial Crisis.” International Journal on Media Management 19(2): 164-181.

Percival, N. and Hesmondhalgh, D. 2014. "Unpaid work in the UK television and film industries: Resistance and changing attitudes." European Journal of Communication 29 (2): 188-203.

Poveda Criado, M. A. 2015. "Sources of funding of Spanish audiovisual.” Opción 31 (Special Issue 2): 877-886.

Ribera, J., and Sieber, S. 2009. "How uncertainty and risk management impacts the success of Spanish film projects.” Journal of Media Business Studies 6 (4): 49-74.

Romaguera i Ramió, J., and Alsina Thevenet, H. 1998. Textos y manifiestos del cine. Madrid: Cátedra.

Rubio Alcover, A. 2010. "El Dogma danés.” Available online at: http://www.bocc.ubi.pt/pag/alcover-rubio-el-dogma-danes.pdf

Rubio Alcover, A. 2014. "Explorers of Chaos, Strategists of the Abyss: Cartography of the Far Side of Contemporary Spanish Cinema." Fonseca, Journal of Communication 9: 11-27.

Sanson, K. 2014. "Location and labor: critical crossroads in global film and television." Creative Industries Journal 7 (1): 54-58.

Shaviro, S. 2010. Post-cinematic affect. Winchester: O-Books.

Smith, P. J. 2009. "Film culture in Madrid.” Film Quarterly 62 (4): 63-68. 
Spain Film Commission. 2017. Film Industry Facts. Madrid: The Spain Film Commission Network.

Thanouli, E. 2009. Post-Classical Cinema: An International Poetics of Film Narration. London: Wallflower Press.

Triana-Toribio, N. 2008. "Auterism and commerce in contemporary Spanish cinema: directores mediáticos." Screen 49 (3): 259-276.

van Liew, M. 2010. "New modernity, transnational women, and Spanish cinema." Comparative Literature and Culture 12 (2): 1-10.

Wheeler, D. 2014. “Two Decades of Cinematic Production and Critical Discourse." In (Re)Viewing Creative, Critical and Commercial Practices in Contemporary Spanish Cinema, edited by D. Wheeler and F. Canet, 7-34, Bristol: Intellect.

Wirtz, B. W., Mermann, M., and Daiser, P. 2016. "Success factors of motion picture actors an empirical analysis." Creative Industries Journal 9 (2): 162-180.

\section{Table with caption}

Table 1. List of films comprising the sample: \#Littlesecretfilms released in 2013-2014. Source of online viewing data: official profiles of directors, producers and films on YouTube and Vimeo [last update January 2018].

\begin{tabular}{|c|c|c|c|c|c|}
\hline Title & Directed by & $\begin{array}{c}\text { Release } \\
\text { date }\end{array}$ & $\begin{array}{c}\text { Produced by } \\
\text { Calle13 }\end{array}$ & Online views & $\begin{array}{c}\text { Running } \\
\text { time }\end{array}$ \\
\hline 16th Folk Room & Víctor Alonso & $29 / 1 / 13$ & - & 3,841 & 01:00:02 \\
\hline $\begin{array}{c}\text { Los desórdenes } \\
\text { sentimentales }\end{array}$ & Ramón Alfonso & $31 / 1 / 13$ & - & 5,544 & 01:30:10 \\
\hline $\begin{array}{l}\text { Nuestro porno } \\
\text { favorito }\end{array}$ & Carlo Padial & $31 / 1 / 13$ & - & 141,594 & 00:11:07 \\
\hline $\begin{array}{l}\text { Manic Pixie Dream } \\
\text { Girl (An Internet love } \\
\text { story) }\end{array}$ & Pablo Maqueda & $01 / 02 / 2013$ & - & 26,200 & 01:10:01 \\
\hline $\begin{array}{c}\text { Piccolo Grande } \\
\text { amore }\end{array}$ & Jordi Costa & $01 / 02 / 2013$ & - & 14,300 & 1:28:06 \\
\hline Cinema Verité, Verité & Elena Manrique & $01 / 02 / 2013$ & - & 0 & 59:10:00 \\
\hline Nova & Bruno Teixidor & $01 / 02 / 2013$ & - & 14,242 & 01:00:06 \\
\hline
\end{tabular}




\begin{tabular}{|c|c|c|c|c|c|}
\hline Undo infinito & Álex Mendíbil & 01/02/2013 & - & 2,102 & 01:09:07 \\
\hline La pájara & Jimina Sabadú & 01/02/2013 & - & 0 & $00: 40: 36$ \\
\hline $\begin{array}{c}\text { KILN. Proyecto Z24 } \\
\text { 14B1 }\end{array}$ & Héctor G. Barnés & $01 / 02 / 2013$ & - & 1,421 & 01:09:54 \\
\hline Iron Cock Unchained & $\begin{array}{c}\text { Manel Junio, Patxi Maiza \& Ibie } \\
\text { Romero }\end{array}$ & $01 / 02 / 2013$ & - & 4,278 & 01:00:00 \\
\hline Anfibia & Hugo Álvarez Gómez & $01 / 02 / 2013$ & - & 2,458 & $00: 38: 52$ \\
\hline Working Progress & Roland de Middel & $22 / 04 / 2013$ & - & 0 & 01:09:05 \\
\hline Hamelín & Carlos Rivero \& Alonso Valbuena & $22 / 04 / 2013$ & - & 2,730 & 01:02:20 \\
\hline Dos tristes tigres & Julián Teurlais \& David Ortiz & $22 / 04 / 2013$ & - & 1,602 & 01:18:29 \\
\hline $\begin{array}{l}\text { Desmadre en la } \\
\text { noche de la quietud }\end{array}$ & Pablo Vázquez & 01/05/2013 & - & 3,449 & $01: 44: 18$ \\
\hline $\begin{array}{l}\text { Nunca he estado en } \\
\text { Poughkeepsie }\end{array}$ & Ángel Sala & $12 / 07 / 2013$ & Yes & 0 & 01:00:00 \\
\hline \#RealMovie & Pablo Maqueda & 29/07/2013 & Yes & 91 & 00:58:00 \\
\hline Estado de regresión & Álex Mendíbil & 26/09/2013 & Yes & 124 & 01:21:50 \\
\hline La lava en los labios & Jordi Costa & $26 / 10 / 2013$ & Yes & 0 & 01:13:00 \\
\hline Uranes & Chema García Ibarra & 28/10/2013 & Yes & 0 & 01:00:00 \\
\hline Obra 67 & David Sainz & $15 / 11 / 2013$ & Yes & 0 & 01:48:00 \\
\hline Todos tus secretos & Manuel Bartual & 23/01/2014 & Yes & 0 & 01:22:00 \\
\hline Los amigos raros & Roberto Pérez Toledo & $31 / 03 / 2014$ & Yes & $2,752,578$ & 01:00:16 \\
\hline Círculo interno & John Tones \& Noel Ceballos & 26/04/2014 & Yes & 149 & 00:57:08 \\
\hline Neuroworld & Borja Crespo & $15 / 05 / 2014$ & Yes & 142 & 01:05:29 \\
\hline $\begin{array}{l}\text { Todo el mundo lo } \\
\text { sabe }\end{array}$ & Miguel Larraya & 02/06/2014 & Yes & 169 & 01:13:01 \\
\hline Detective Deketto & Venga Monjas & 27/09/2014 & Yes & 52,299 & $00: 31: 49$ \\
\hline Amor eterno & Marçal Forès & 04/10/2014 & Yes & 0 & 01:09:00 \\
\hline \multicolumn{6}{|c|}{$3,029,313$} \\
\hline \multicolumn{6}{|c|}{ w/o Los Amigos Raros } \\
\hline
\end{tabular}

\section{Figure with caption}

Figure 1. Evolution of the number of Spanish feature films released between 2004 and 2014 (bottom row). Source: Boletín informativo 2014 (Ministerio de Educación, Cultura y Deporte, 2014). 


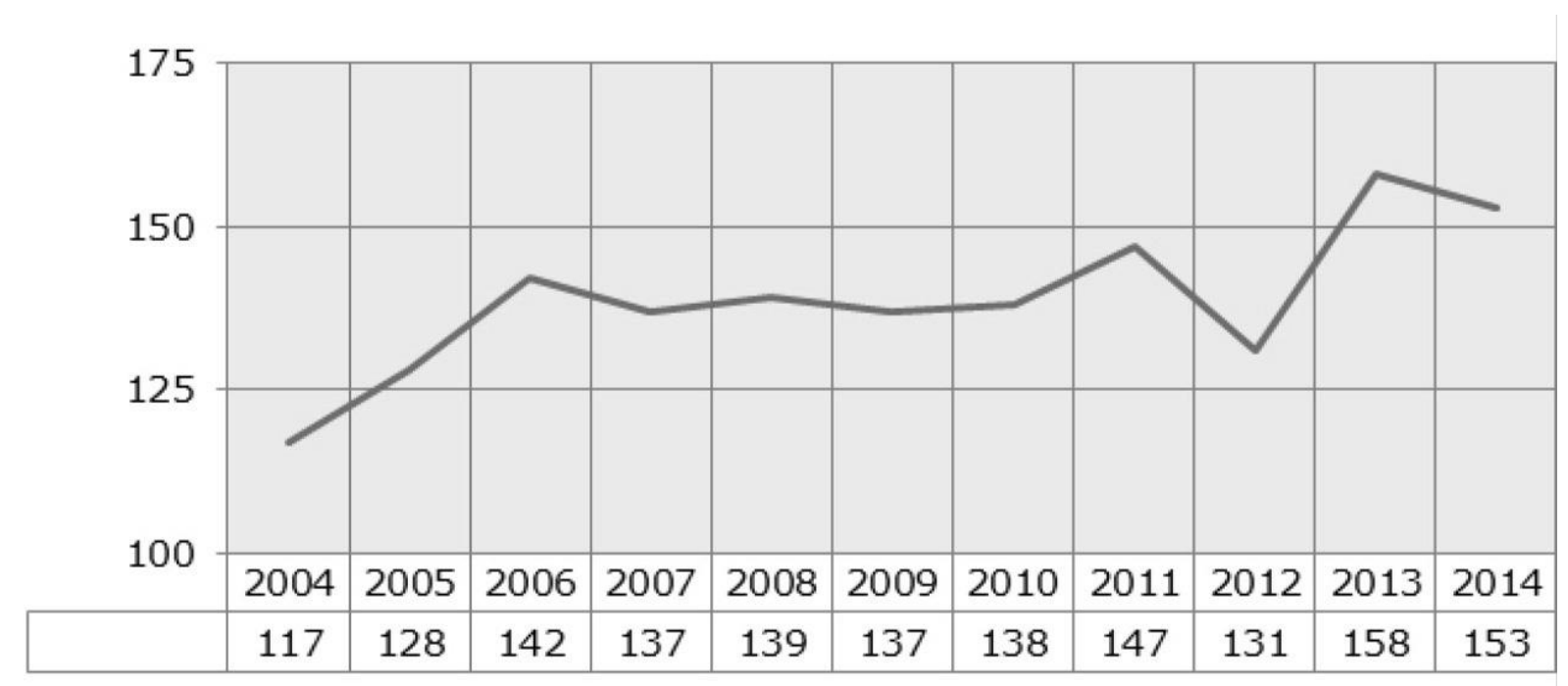

